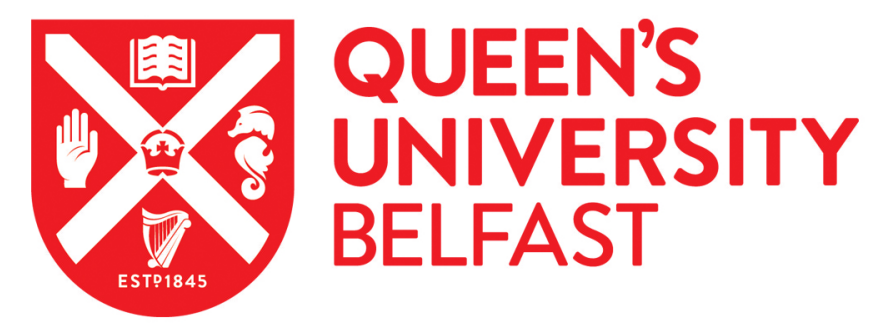

\title{
Gathering communities: locality, rulership and governance in early medieval Ireland
}

Gleeson, P. (2018). Gathering communities: locality, rulership and governance in early medieval Ireland. World Archaeology, 50(1), 100-120. https://doi.org/10.1080/00438243.2018.1473163

\author{
Published in: \\ World Archaeology
}

Document Version:

Peer reviewed version

Queen's University Belfast - Research Portal:

Link to publication record in Queen's University Belfast Research Portal

Publisher rights

(c) 2018 Informa UK Limited, trading as Taylor \& Francis Group. This work is made available online in accordance with the publisher's policies. Please refer to any applicable terms of use of the publisher.

\section{General rights}

Copyright for the publications made accessible via the Queen's University Belfast Research Portal is retained by the author(s) and / or other copyright owners and it is a condition of accessing these publications that users recognise and abide by the legal requirements associated with these rights.

Take down policy

The Research Portal is Queen's institutional repository that provides access to Queen's research output. Every effort has been made to ensure that content in the Research Portal does not infringe any person's rights, or applicable UK laws. If you discover content in the Research Portal that you believe breaches copyright or violates any law, please contact openaccess@qub.ac.uk. 
Title: Gathering communities: locality and rulership in early medieval Ireland

Author: Dr Patrick Gleeson

Contact details: Lecturer in Early Medieval Archaeology, Archaeology and Paleoecology, School of Natural and Built Environment, Queen's University Belfast, BT71NN, UK; Email: P.Gleeson@qub.ac.uk; Phone: +44 (0)2890 973826 


\begin{abstract}
This article explores the role that gatherings and temporary assembly places played in creating communities and manufacturing early polities and kingdoms. Whereas the archaeological dimension to polity building has often focused upon monumentality in programmes of political articulation, the role of more ephemeral activities is equally meaningful but nevertheless under-appreciated. With new research into assembly culture in $1^{\text {st }}$-millennium AD Europe developing apace, the role of gatherings of various types has come into sharper focus. This article explores the changing nature of temporary gatherings in Ireland and what the changing material signature of these practices says about developing hierarchies, emerging kingdoms and the nexus that local concerns formed with regional practices of rulership.
\end{abstract}

Keywords: early medieval; kingdoms; assembly; governance; locality; community

\title{
Introduction: assembling a northern European discourse
}

Recent decades have seen places and practices of assembly emerge as a dynamic field of firstmillennium AD research in Europe, with scholarship in Britain, Scandinavia and to a lesser degree, Ireland, engaged in systematic study of the material expression and mentalities of assembly. These developments have seen 'assembly landscapes' become the focus of research in projects examining royal governance, collective identity, long-term landscape organisation, monument re-use, kingdom-/state-formation and the evolution of legal frameworks (e.g. Barnwell and Mostert 2003; Sanmark et al. 2013; 2015; Sanmark and Semple 2013; Sanmark 2017; Pantos and Semple 2004). Studies of assembly in Ireland have, however, been more limited and sometimes problematic: Elizabeth FitzPatrick's (2004) magisterial study of royal inauguration is paradoxically the only comprehensive analysis to date, for example (also Hicks 2011; Johnston and Wailes 2007; Schot et al. 2011; Waddell et al. 2009). Nevertheless, recent research has re-examined how assembly practices are approached, with dedicated studies of assembly places having highlighted diverse new categories of sites that allow more nuanced understandings to be developed, not only of early medieval assembly cultures, but of the mentality associated with temporary gatherings and transient action more generally (FitzPatrick 2001; 2017; Gleeson 2014; 2015; Gleeson and Ó Carragáin 2016). Accordingly, this article reviews the archaeological character of assembly practices in Ireland, and how a phenomenon of transient activities and temporary gathering is manifest materially and spatially. It explores firstly problems with identifying assembly places, before briefly addressing evidence for temporary, purpose-built structures, and finally, how the changing 
character of gathering places in Ireland illuminates the role of assembly in creating kingdoms, hierarchies, and fostering structures of administration.

It is well established that societies across early medieval Europe had assemblies from an early date, commonly at well-defined and relatively enduring locations that were specifically set apart as assembly places (see Brink 2004; Storli 2011; Sanmark 2017). In Ireland, scholarship employs the term 'assembly' slightly more generically to refer to a suite of 'royal' places of the Iron Age and medieval periods. For instance, ceremonial landscapes, places associated with inauguration, royal caputs, or institutionalised practices of assembly are often lumped together and termed assembly places (e.g. FitzPatrick 2004; Hicks 2011; Johnston et al. 2014; Waddell et al. 2009). While some places could fulfil all of these functions, there is equally good evidence to suggest that assembly places were more commonly a discreet category of site in Ireland too, sometimes located in the same royal estates as caputs or inauguration foci, but often also located at some remove (Gleeson 2015; cf. Warner 2004). Thus, this latter locational distinction suggests that like Anglo-Saxon England or Scandinavia, assemblies were held at places specifically set-aside for the purposes of episodic gatherings (e.g. Storli 2010; Sanmark and Semple 2013). Correspondingly, there is good evidence that such places were specifically associated with the principal assembly of Irish kingdoms, known as an óenach (plural óenaig, from a root word meaning 'one', and connoting a concept of unification; further defined below). These assemblies took place on defined royal estates called mruig ríg, namely 'royal demesne', that was held as a prerogative of the office of kingship (see Kelly 1997, 138 and 403-4). Despite the importance of this fact, locating these óenach assembly places and their associated royal estates is beset with certain problems, however.

Famously in an early medieval European context, the political landscape of Ireland is distinctive for being defined by intensely local identities and a hierarchy of kingship that ensures several inter-linked degrees of regality, and indeed, assembly. Túath (plural túatha) was a term that literally meant 'community', but in its semantic range encompassed kingdoms of varying sizes, from those of no more than ten kilometres in extent, to whole regions and provinces. In a most basic and geo-political sense, however, túath references the territorial and semi-autonomous polities that formed the building blocks of kingdoms and the early Irish geopolitical landscape, and who, at one time or another were ruled by a king or toísech (plural toísig, 'leaders'). The latter, toísech, may or may not be drawn from royal lineages, but were analogous to a 'king' or a 'leader' nonetheless. Thus, based on the number of túatha we can 
estimate to have existed in early medieval Ireland, the number of polities and rulers that existed simultaneously might range from 600 to 1500 or more (see MacCotter 2008; 2012). Consequently, this presents a multiplicity of rulers that contrasts starkly with elsewhere in early medieval Europe, where despite evidence for comparable hierarchies of kingship, kings were altogether more rare, powerful and regional in scope. Nevertheless, for present concerns this ubiquity of kings means a corresponding ubiquity of assembly places; at least 600 for example, but as intimated, perhaps a great deal more (Gleeson 2014; see also MacCotter 2008; Ó Corráin 1978). Only seventy-eight assembly places are documented in medieval sources, however, with some alternate names describing the same assembly place (Hogan 1910, 558-9; see now Ó Ríain et al. 2003, 60-6). The Óenach Project addressed this wider issue by developing interdisciplinary methodologies for identifying assembly places, and through a combination of archaeological and landscape analysis, toponymy and documentary sources, succeeded in identifying c.120 assembly landscapes (Figure 1; Gleeson 2014, 798-901). Some of these identifications are tentative, but cumulatively they have facilitated the recognition of a specific archaeological phenomena that helps to identify assembly places more generally. Two key conclusions are pertinent presently: (i) there is no single monumental characteristic of assembly landscapes (contra Hicks 2011; see also FitzPatrick 2004; 2015; FitzPatrick and Hennessey 2017); (ii) a very strong correlation exists between assembly places and foci of burial, with a corpus of sites known as 'cemetery settlements' or 'settlement cemeteries' discovered through developer-led archaeology in the 1990s-2010s. In fact, these latter sites are likely to be places of local gathering for these túath(a), the minimal polity of medieval Ireland, and those local geo-political entities ruled by kings or toísig, as noted above (Figure 1; MacCotter 2008; 2012; Gleeson 2015). The case for identifying these complexes as local assembly places has been laid out extensively elsewhere (Gleeson 2014; 2015): places of burial, whether isolated internments, un-enclosed field cemeteries or cemetery enclosures with or without evidence for associated habitation, tend to cluster in the same landscapes, more often than not around their boundaries, and these can be identified through toponyms or documentary evidence as assembly places. Alongside conversion-period churches, these complexes and funerary foci were defining these landscapes as royal estates and assembly places by at least the $5^{\text {th }}$ to $6^{\text {th }}$ century (e.g. Gleeson and Ó Carragáin 2016). The funerary component of these complexes begins to fall-off from the later $7^{\text {th }}$ century (Ó Carragáin 2009; 2010; O’Brien 2009), but some complexes often remained in use for other activities down to the $9^{\text {th }}, 10^{\text {th }}$, and $11^{\text {th }}$ century as well as in some cases a deal later (e.g. O'Sullivan et al. 2013, 306-12; below). In so far as these cemetery settlements may now be understood as local assembly places, such a reading 
simultaneously addresses issues surrounding the large numbers of discrete assembly places that we can hypothesise from models of the early Irish polity. Namely that while at least 600 assembly places might be expected to have existed at any one time, only 78 óenaig are documented and only c.120 assembly landscapes were identified by The Óenach Project. Thus, cemetery foci that cluster together within assembly landscapes themselves represent discreet foci of assembly appropriate to different scales of polity, community and gathering, which mirror the hierarchies of rulership that defined the politics in early medieval Ireland. It is the ephemeral and transient nature of gathering within these landscapes that has occluded their active social role and recognition as assembly places.

With regard to early medieval assemblies in Ireland, in comparative terms these funerary complexes define local túath-scale assembly places that parallel hundred assemblies in AngloSaxon England, skipjeider- or minor thing-level assemblies in Scandinavia, with the higher order assembly that these Irish communities were subject to in these same landscapes, the óenach, a better parallel the shire or higher-order assemblies of eastern Britain and Scandinavia (see Brookes and Reynolds 2012; Sanmark 2017; Iversen 2013; 2015; Ødegaard 2013). Although popularly and commonly translated 'fair/market', an óenach was rather the political assembly par excellence of early medieval Ireland. It may have been an annual or bi-annual assembly convened for calendrical festival like the harvest in early August, but associated with the promulgation of laws, legal proceedings, rendering and redistributing of tribute, horse- and chariot-racing, and more general merriment and entertainment (Etchingham 2010; Gleeson $2014 ; 2015)$. As the principal assembly of each kingdom, it can appropriately be set beside these other northern European comparanda. This is notable too because the character of cemetery settlements as assembly places associated with óenaig parallels the archaeological dimensions of assembly practices elsewhere; for example, at Saltwood, Kent, an assembly place for Heane Hundred was defined by a number of early Anglo-Saxon cemeteries with evidence for feasting and the remains of other temporary and episodic activities (Brookes and Reynolds 2011; Booth et al. 2011; see also Semple 2004; Williams 2004, 110-3). This recognition of the assembly function for cemeteries in Ireland and elsewhere facilitates recognising a key material expression of the socio-political character of practices of gathering in early medieval society, in spite of their transience and inherently ephemeral nature.

Here, one must draw a distinction between the archaeology of assembly places and an archaeology of assembly practices. An archaeology of assembly practices describes something 
more distinctive and capable of archaeological analysis. Indeed, a mound may be an integral aspect of the monumentality of assembly places, but this dimension of assembly may be the product of very particular exigencies that themselves manifest the changing nature of assembly in 8th-century Ireland (below). Thus, the archaeology of assembly practices might include purpose-built structures, stray finds, evidence for periodic feasting, crop-processing and craftworking, while equally, the character of particular landscapes within their local territorial frameworks or estate structures. Notably, many of these elements need leave little or no physical traces, despite being fundamental to social cohesion. An association between assembly and mounds, admittedly a pan-European phenomenon, is not ubiquitous; mounds purpose-built or converted for use during assemblies are known from Ireland, Anglo-Saxon England and elsewhere (e.g. Adkins and Petchey 1984; FitzPatrick 2004, 35; Sanmark 2017), but some assembly places were defined by natural features like a knoll (below), and were remarkably unmonumental. Thus a mound, whether purpose-built, ancient and sepulchral, or indeed natural, describes an aspect of assembly practices, not a prerequisite for assembly places.

\section{Archaeology and Óenaig}

In so far as temporary structures for assembly can be identified, the Knockans at Teltown is a purpose-built structure in Ireland, but of exactly what sort remains debatable: a structure for seating, avenue and a place for coursing animals have been mooted (Fitzpatrick 2015; Newman 2007; Swift 2000). Law tracts refer to proscriptions on the preparation of assembly places (denam óenaig), erection of temporary structures, clearing gorse, weeds, maintenance of roadways, and enigmatic structures known as forrad (e.g. Dillon 1932, 61-2; Swift 1996; 2000). Doherty (1985) argues that forrad signifies an inauguration mound. This is one pertinent example of how assembly and inauguration have become conflated categories of royal practice in Ireland, but nevertheless, multiple forrad could be located in close proximity to each other in literary accounts of assembly places, and some were clearly not mounds, but purpose-built, temporary and flimsy. Likewise, FitzPatrick $(2004,81-7)$ highlights diminutive earth and stone platforms atop ceremonial mounds that might be connected with forrad, while small structures atop mounds are known from excavations (Warner 2000, 46). Similarly, mounds used for assembly in Scandinavia were often not flat-topped (Sanmark 2017, 84), though whether for seating or something else remains uncertain. 
If a mound is not therefore as integal to assembly places as often assumed, archaeology is slowly finding firmer footing in understanding óenaig through developing archaeologies of assembly practices. These include the necessities of gathering together, feeding, accomodating and organising large groups of people, as well as activities associated with such groups during assemblies. In Ireland óenach functioned as the principal form of early medieval assembly and was probably a bi-annual and general gathering of a kingdom, but one that we can expect to have run concurrently with lower-order more regular assemblies (e.g. a dál or aireacht, both 'assembly', but with perhaps a legal imperative). The major activities associated with an óenach can be gleaned from law tracts, saga, gnomic literature, annals, hagiography and dindshenchas (place lore of the 11th-12th centuries), and detailed consideration can be found elsewhere (Swift 2000; Etchingham 2010, 38-52). Óenaig were above all associated with horse- and chariot-racing, general merriment and entertainment, the rendering and redistributing of tribute, the promulgation of laws, the negotiation of inter-polity relations, perhaps law courts and sometimes church synods that ran concurrently. These were thus multifunctional assemblies with pronounced sociopolitical roles and central to local communities and civil society. With this in mind we can proceed to considering the characteristics of five case studies of assembly landscapes connected with regional kingdoms, but where each several discrete foci represents the local assembly of a lower order túath (Figure 2).

\section{Óenach Maonmaighe}

The kingdom of Máenmag was ruled by the Clann Chommáin, whose metonymic style as rí Locha Riach (MacCotter 2008, 141), denotes a royal seat about Loughrea, Co. Galway. A large stepped mound in Masonbrook may intimate a locus of inauguration (Fitzpatrick 2004, 48), but the placename Knocknadaula, probably Cnoc Ard Dála, 'high mountain of the assemblies' (Logainm; cf. Killimordaly: Cill Íomar Uí Dhálaigh), provides a suggestive assembly toponym, probably synonymous with Óenach Maoinmaighe. The wider landscape boasts the famous $L a$ Téne-decorated Turoe Stone as well as Carrowkeel, a burial complex containing 132 individuals established in the late 7th century AD (Lehane et al. 2010); Cross, where two annular ring-ditches contained cremations and inhumations dated to the 4th-6th centuries AD (Mullins 2007; Mapping Death); and Farta, where a mound covered an extended east-west orientated female inhumation of AD 383-538, accompanied by a complete horse-skeleton and red deer antler (Coffey 1904; Mapping Death). Farta derives from ferta, which is an early medieval term meaning an ancestral burial placea and expressly associated with burial that 
demarcated territorial boundaries (see O'Brien and Bhreathnach 2011). For brevity, discussion may focus on Carrowkeel.

A series of shallow linear and curvilinear ditches preceded a main enclosure c. $60 \mathrm{~m}$ in diameter. This contained a smaller centrally-placed enclosure defining a burial precinct containing adult male, female and juvenile burials, and spanning four discreet 7 th- to 15 th-century phases. The majority of inhumations concentrated in Phases 1-2 (7th-11th century), with a series of postholes (not defining a structure) to the northeast, and pits, including a large oblong pit filled with burnt sediments and used for cooking to the north (Lehane et al. 2010). Despite the absence of domestic structures in the form of houses or hearths, there was a large animal bone assemblage. Cattle dominated, but with pig, sheep and horse also present. Butchery waste and food debris indicated that food was being prepared, processed and consumed on site, while artefacts that included pins, a knife, hook and iron slag were recovered from the ditch (ibid. $143)$.

\section{Óenach Carmain}

This royal assembly of the province of Leinster in southeast Ireland and located just north of Dún Ailinne, the symbolic capital of that province. Carmain encompassed a royal estate containing the parishes of Coughlanstown and Carnalway. The centrepiece of this landscape was a low hill crowned by a barrow known as Silliothill, with the barrow itself intimated by the parish name, Carnalway, from Carn Ailbhe, namely 'the cairn of Ailbhe'. During the $5^{\text {th }}$ century $\mathrm{AD}$ this landscape and estate surrounding Silliothill was defined by a series of cemeteries that included examples at Corbally/Brownstown, Mullacash, Greenhills and perhaps Coughlanstown. Of these Corbally and Greenhills can be associated with túatha of Dál Messin Corb, the Uí Bairche and Dál Cormaic Loisc (Figure 3: MacCotter 2016; Gleeson and Ó Carragáin 2016).

The cemeteries surrounding this landscape show a large and poly-focal funerary landscape, and while only small numbers of burials have been found at Coughlanstown and Mullacash Greenhills and Corbally are more extensive. Greenhills describes a linear inhumation cemetery located to the east of a ring-ditch containing a founder grave, but associated with a large linear ditch, numerous pits, postholes and a hearth (Keeley 1991). Corbally is much more extensive, and encompasses a number of discreet funerary foci: ring-ditches containing multiple burials, but with a larger enclosed cemetery describing the principle element. This larger cemetery 
developed around a primary $5^{\text {th }}$-century grave, before being enlarged twice during the $6^{\text {th }}$ and $7^{\text {th }}$ centuries to accommodate the growing cemetery (Figure 4; Coyne 2010, 80-4). Outside of this enclosure, and encompassing the other funerary foci was an extensive system of intercutting ditches and annexed enclosures likely to have contained animals or specialised activities (Figure 4). Adult burial seems to have ceased in the later $7^{\text {th }}$ century, though juvenile burial continued, and the complex as a whole remained in use down to at least the $9^{\text {th }}$ century. The only structure excavated was a small sunken building perhaps used for textile-working, while the assemblage from the site shows craft- and iron-working, as well as feasting through a large collection of animal remains and food waste (Coyne 2010; Gleeson and Ó Carragáin 2016). Most significantly the broader complex included at least thirty grain-drying kilns showing large scale crop-processing (Coyne 2010; Tobin 2003).

\section{Óenach Muirtheimne}

The kingdom of Conaille Muirtheimne encompassed much of modern day Co. Louth, with a principal assembly at Óenach Muirtheimne, likely the assembly of the broader over-kingdom, and a place defined by Carrickaneena, from Carrig an Óenach, suggesting an assembly focused upon a hilltop rock outcrop named 'Claret Rock'. This outcrop has been artificially enhanced through a low masonry wall constructed atop the knoll (Figure 5). To the south of Carrickaneena is Faughaurt Hill, home to an important early medieval church dedicated to St. Brigid and a large mound, perhaps a motte but conceivably an earlier sepulchral mound. Further to the south of Faughaurt Hill the construction of the M1 discovered cemetery complexes at Faughaurt Lower and Balriggan 1 (Figure 6).

Faughaurt Lower began as a bivallate enclosure with four phases of activity and a cemetery containing 772 burials. Partly as a result of this cemetery's growth, the site was expanded in Phases 3 and 4, but no structures or normal habitation evidence was identified in any phase. Instead, the construction of a palisade around part of the northern entrance in Phase 2 suggests an attempt to regulate access to the centre of the site, while what the excavator termed industrial activity shows the use of the wider complex for multiple activities. Animal bone and souterrain ware suggests the preparation and consumption of food on a large scale, while the presence of metal and slag suggest a degree of production (Buckley and McConway 2010, 49-51). This latter element of the site became accentuated in Phases 3 and 4, when a souterrain (for underground storage) was constructed, while the presence of crucible fragments, a lead ingot, 
pins, bone combs, and several millstone fragments suggest metal- and textile-working as well as the large-scale grinding of grain (ibid. 51-3).

Further west at Balriggan activity began in the earlier first millennium AD, when a grain-drying kiln and a circular enclosed structure at Fort Hill suggest a focus of activity. The 5th to 7th century, however, saw the construction of Enclosure A on the edge of a wetland area, with a cemetery focused on its southern portion, and an industrial area to the northeast that included six large irregular pits (Delaney 2010, 90-5). Some pits may have been lined, and they were filled with spreads of ash, pottery and mettalurgical waste. The presence of an iron punch and small quantities of slag suggests production. Outside of Enclosure A a large external and concentric enclosure (Enclosure B) defined a berm in which linear ditches and a series of small enclosures suggests paddocks and areas for specialised activities. A structured entrance from the southwest led to the cemetery area and this also contained two structures: a square fourpost structure and a rectangular east-west aligned nine-post building. These were not normal habitations: the large rectangular structure could have been a church, but both it and the four post structure have been interpreted as raised structures for storing grain. Their position at either side of the entrance is notable in this regard, as it suggests a conspicuous position designed to be seen upon entering the cemetery precinct. That grain was being stored and processed on the site is also suggested by the addition of a horizontal mill to the southeast of the burial area, where an undercroft and mill-race have been excavated (ibid. 96-101).

Between Enclosure A and Fort Hill was Enclosure C, a large (c.58m diameter) enclosure focued on the east-facing slope of the highest point of a natural knoll. This meant that the enclosure faced onto the cemetery and Enclosure B complex. Despite an elaborate funnelled entrance, the site was sterile with no archaeological features identified internally. This could be a stock enclosure, as suggested by the excavator, but given its position over-looking the cemetery, it may also have been the focus of gatherings for the group buried therein. To the south a grain-drying kiln, a metal-smithing area and two pits filled with charcoal showing signs of in situ suggest a production and cooking area (ibid. 96-7). Again, spindle-whorls, loomweights, a punch and an awl suggest textile working, while metal-working is also testified in metallurgical waste and a variety of worked stones. The presence of a number of quernstones suggests small-scale crop processing in addition to the larger-scale mill. 
The animal bone assemblage was dominated by cattle but also included pig, sheep/goat, red deer, fish, dog and horse. A higher frequency of extremities amongst the cattle bone might suggest that meat rich cuts were being retrieved and brought to site for consumption, while the red deer remains suggest hunting, the consumption of game, and perhaps antler-working. Intriguingly, as least five horses from the assemblage did not show evidence for butchery (ibid. 101), and might therefore be explained as casualties in the horse- or chariot-racing associated with assemblies; the danger of injury by and to horses at óenaig is specifically highlighted by laws and gnomic sources (e.g. Kelly 1976, 8-9).

\section{Óenach in Bhroga}

Knowth, Co. Meath was a major royal site of Síl nÁedo Sláine, a dynastic sub-segment of the Uí Néill who controlled an over- kingdom named Brega centred on much of modern day Cos. Meath, Dublin and Louth (Eogan 2012; Byrne 1968). Knowth is most famous for being a Neolithic passage tomb, but from the $7^{\text {th }}$ it was re-used by Síl nÁedo Sláine, and alongside the rest of Brú na Bóinne (the Bend of the Boyne, including Newgrange) was a documented assembly landscape, Óenach in Bhroga (Ó Riain et al. 2003, 61). The presence of local assembly foci within the environs of Knowth is suggested by Site M, a $7^{\text {th }}$ - to $9^{\text {th }}$-century cemetery complex to the north of Knowth, as well as a cemetery at Knowth itself (Stout and Stout 2008; Eogan 2012, 45-82).

The great mound of Knowth is surrounded by smaller satellite tombs, and in the later $7^{\text {th }}$ century these became the focus of a royal cemetery until the early $9^{\text {th }}$ century. Site $M$ was constructed contemporaneously, but so too was the great mound remodelled. Rather than being a ringfort (a standard early medieval settlement enclosure, c.60000 of which are dotted around the Irish landscape), the presence of a large V-profiled ditch dig into the passage tomb kerb, and a higher L-profiled terrace cut into the mound material suggest that this remodelling intended to appropriate the great mound as an assembly and/or inauguration mound (Eogan 2012, 71-3; further Gleeson 2014). That no structures of hearths were recovered from the crest of the mound supports that conclusion, as does the fact that the tomb passages were entered at this stage. Furthermore, the orthostats within the passage were inscribed during the $8^{\text {th }}$ and $9^{\text {th }}$ century with half uncial script and scholastic ogham (see Swift 2009).

Subsequently, the $9^{\text {th }}-11^{\text {th }}$ centuries saw drastic change: the cemetery fell out of use, as did Site $\mathrm{M}$ to the north, and a series of souterrains were constructed alongside several large structures 
on the crest and terrace of the mound (Eogan 2012, 86-7 and 96-105). Many of these structures are unlikely to be habitations: some were associated with metal-working, but others were rather flimsy and lacked centrally-placed hearths or divisions (see Wallace in Eogan 2012).

\section{Óenach Téide/Urmumhan}

Nenagh, Co. Tipperary, derives from an t-Aonach, 'the óenach/assembly', and although located in the kingdom of Muscraige Tíre, was the assembly place for the kingdom of East Munster (approximately modern-day Cos. Tipperary and Kilkenny) named Óenach Téide/Urmumhan. Just outside Nenagh in the townland of Carrigatogher-Harding along the M7, a major cemetery was excavated. Carrigatogher means 'stone of the togher/road' (Logainm) indicating proximity to the Sligh Dála, 'road of assemblies', that passed through Nenagh (Figure 7; for the Sligh Dála, see Ó Lochlainn 1940). This cemetery of fifty-six eastwest extended inhumations was enclosed and expanded incrementally as the site developed. The principal focus of the burials was a natural knoll, possibly mistaken for an ancient burial mound, but acidic soil means that skeletal material was not preserved. Associated occupation debris indicates use between the 6th and $9^{\text {th }}$ centuries, with spindle-whorls, pins, needles and iron waste suggesting metal-, craft-and textile-working, and a kiln outside the enclosure suggesting crop-processing (Taylor 2010, 288-90). Immediately southwest of the entrance a rectangular structure $(12 \mathrm{~m} \times 5 \mathrm{~m})$ was defined by a slot-trench to the northwest, a set of 15 postholes on the southern side, and orientated towards the burial area (ibid., 288). Its exact function is unknown, but being overlain by a spread of occupation material it was dismantled while the site was still in use (ibid.), making a church unlikely; a granary, like Balriggan, or a mortuary house might seem plausible. Further evidence for burial in the wider landscape includes a barrow cemetery in Knockanpierce, and two isolated $7^{\text {th }}$ - to $10^{\text {th }}$-century burials from St. Conlon's Road, one with peri-mortem trauma to the ribs, and the other a decapitation, suggesting a possible execution cemetery (Collins and Lynch 2006).

At Carrigatogher burial appears to have ceased in the $8^{\text {th }}$ century, when activity thereafter shifts to nearby Tullaheady. Here excavation has shown that a natural knoll was converted into a low mound during the 8th-9th centuries (Figure 7; Cleary and Kelleher 2011, 429-31). Subsequently, a large volume of animal bone, fifteen hone stones and some slag, as well as several pits containing charred seeds, charcoal and hazelnut shells, suggest that this became a focus of feasting activities. Notably, there was evidence that the ditch was periodically cleaned out, and it is distinctly plausible that this monument was consciously fashioned in the 8th-9th 
century as an assembly mound. Here, the townland name Tullaheady becomes significant. Óenach Urmumhan was also known as Óenach Téide, the 'assembly of Téíde', intimating a mythical female ancestress imagined to be interred in a burial mound celebrated through assemblies (see Ettlinger 1953). Tullaheady may derive from Tulach Téite, 'the burial mound/hill of Téite', and very likely suggests that the knoll and complex at Tullaheady is the assembly mound on which the wider landscape focused. That activity shifted here in the $8^{\text {th }}$ century, replacing Carrigatogher and perhaps other complexes, suggests a process of mythologisation paralleled at Knowth, but tellingly, one that involved centralisation and the focusing of the wider landscape on a key central monument.

\section{Making kingdoms and creating communities}

Striking similarities between these complexes include a shared monumentality, emphasis on burial, often with multiple foci, feasting, production and processing, but a near complete absence of structures or normal habitations that allow them to be identified as settlements and habitations. Much more so, they parallel sites found throughout northwest Europe that show temporary gathering and feasting activities commonly occurring at cemeteries. Debate about whether best to term these sites 'cemetery settlements', 'settlement cemeteries' or 'secular cemeteries' now seems misplaced (Stout and Stout 2008; O'Sullivan et al. 2013; Ó Carragáin $2009 ; 2010)$ and they no longer appear to constitute a regional phenomenon in eastern Ireland (pace Stout and Stout 2008). Their concentration in the east reflects the intensity of growth and development in the greater Dublin commuter region though recent decades and sites are now known from the midlands and west. Thus, they may not tell us much about regionality in early medieval monumentalities, but they do illuminate regionality in local responses to processes of polity building, and provide thereby a barometer of how local practices of gathering were implicated in the emergence of regional and supra-regional kingdoms and practices of governance.

The scale of production, processing and feasting, for instance, goes beyond the needs of a normal habitation or familial unit when compared to assemblages excavated from settlement 'ringforts' elsewhere (see O'Sullivan et al. 2013), suggesting in turn that these places and their associated activities were communal in nature. Feasting in particular suggests collective action: the possibility that meat-rich cuts were privileged at Balriggan, for example, reinforces a sense of communal action in generating these assemblages. Likewise, these assemblages imply a 
concentration of resources within these places that also hints at a communal nature, even if their material traces are detritus, ephemeral and somewhat enigmatic. Three aspects of these complexes might usefully form the focus of remaining discussion: hierarchy and burial; production, consumption and surplus; and emerging evidence for the monumentalisation of assembly practices in the $8^{\text {th }}$ century.

We can see at sites like Carrowkeel or Balriggan, how cemeteries were clearly defined, but used for a multitude of other activities in landscapes that were themselves poly-focal. As much as Enclosure A and B at Balriggan alongside Faughart can be identified as components of the same landscape, so too multiple foci in Corbally, Greenhills, Mullacash and Coughlanstown can all be related to the same broader assembly landscape, Óenach Carmain. Nevertheless, there are clear differences between these discrete foci of burial, and the degree to which they were implicated in gatherings. There seems a distinction, for instance, between more inclusive and exclusive places of burial: some sites are small groups of burials, often with a more monumental dimension closer to the boundaries of their respective landscapes (e.g. Farta or Greenhills), whereas others are more inclusive, centrally located and seemingly communal in nature (e.g. Corbally, Carrowkeel or Faughaurt; see Figures 3 and 4 for instance). Interestingly, these larger more complex sites, what we might term community cemeteries (Ó Carragáin $2009 ; 2010)$, tend to be more directly associated with production, feasting and crop-processing evidence too, as at Corbally and Balriggan. The possibility that this distinction in scale, complexity and monumentality relates to hierarchies within these communities being materialised, manufactured and negotiated through mortuary practices, temporary gatherings and collective actions, is intriguing. Might the more exclusive and monumental burials be of ruling lineages, namely the families from which kings, toísig and other local leaders were drawn? If so, then this implicates the concentration of production and processing evidence in the more communal cemeteries in the creation of inter- and intra-polity relationships, of both a familial, lineage and community scale; we might justifiably imagine that the products of production and crop processing at sites like Corbally or Balriggan were used to fulfil the needs of discreet communities, but also the tributes proffered to overlords who commanded allegiance and renders.

While the chronologies for these sites are currently not so refined as to allow detailed discussion of the relative intensity of production activities and processing throughout the early medieval period, there is some proxy evidence to suggest an intensification during the latter 
half of the period. Most of the complex sites continue to show evidence for activity down to the $9^{\text {th }}, 10^{\text {th }}$, and $11^{\text {th }}$ century and even beyond, but in a number of cases burial had ceased by the $7^{\text {th }}$ to $9^{\text {th }}$ centuries. At Corbally, adult burial ceased by c.700, with only juvenile burial thereafter (Coyne 2010; Gleeson and Ó Carragáin 2016), while burial at Knowth and Site M did not much continue past c.800. At sites like Faughaurt and Carrowkeel burial did continue, but it appears to have been markedly less intensive (Lehane et al. 2010, 143; Buckley and McConway 2010, 51). The use of these burial complexes from the $5^{\text {th }}$ to $7^{\text {th }}$ centuries can be understood as part of processes geared to articulate local, kin-based identities relative to more encompassing scales of community, and we might assume that the continued use of these sites in later centuries articulates similar prerogatives, albeit where burial was no longer a key facet (further Gleeson 2014). What seems to have replaced burial in some sense was an emphasis on larger-scale production and processing activities. We might consider thirty kilns from Corbally, or the addition of a mill and souterrain at Balriggan and Faughaurt. Do these developments materialise the demands of more pervasive forms of rulership, and the new role of local assembly places in maintaining hierarchies of governance and administration that under-pinned the functioning of regional kingdoms?

At Corbally, the termination of burial can be connected with the usurpation of Óenach Carmain by Uí Dunláinge, the group who went on to rule most of North Leinster in the $8^{\text {th }}$ to $10^{\text {th }}$ centuries (Gleeson and Ó Carragáin 2016), while at Carrigatogher-Harding, the shift of activity to Tullaheady is contemporary with the earliest reference to a kingdom of East Munster in the $8^{\text {th }}$ century (O'Keeffe 1932,20$)$. At Knowth major structural changes between the $9^{\text {th }}$ to $11^{\text {th }}$ century phases find a most tangible expression in exceptionally large numbers of souterrains. It is clear that Knowth was an important royal site earlier, from the later $7^{\text {th }}$ century, but nonetheless, it is notable that references to a kingship of Knowth are concentrated in the late $8^{\text {th }}$ - to $10^{\text {th }}$-century annals from 789 onwards (see Byrne 1968). Souterrains are monuments that are generally understood as places for the below ground storage of foodstuffs (Clinton 2001). The sheer number at Knowth suggesting by extension the storage of huge quantities of food, presumably the renders received by a king and the royal household, and stored at the principal royal centre for the kingdom. Whether for re-distribution or perhaps sale, the presence of a ready-made market in Hiberno-Norse Dublin is notable. Likewise, a souterrain to Faughaurt, a mill at nearby Balriggan, and evidence for probable granaries at the latter similarly suggests the transformation of local kin-based places of assembly, into nodal points in a network of 
royal centres. These centres could now underpin the governance and the administration of a kingdom, but also perhaps crucially, the demands of a peripatetic royal itinerary.

More work needs to be done to refine the chronologies of these sites, but one area where changes in the archaeological evidence suggest other important developments, is in the area of increasing monumentality. The enclosure complexes that defined gathering places in the $5^{\text {th }}$ to $8^{\text {th }}$ centuries would have been conspicuous in the landscape, and a degree of monumentality is implied by the clear definition of burial precincts and activity areas, either through ditches, or at Balriggan, through the use of topography that ensured Enclosure $\mathrm{C}$ faced and was visible from the main burial area (above). Yet, there is comparatively little evidence for these complexes being defined by imposing and highly visible banks, even though some ditches were re-cut periodically; this slight and very localised monumentality is partly why they proved so elusive in Ireland prior to large scale infrastructural projects of recent decades.

From the $8^{\text {th }}$ century, however, alongside emerging changes to the burial functions of these complexes, we see evidence for a more monumental element at Tullaheady and Knowth. At Tullaheady the digging of a ditch around a natural knoll created a mound that may the eponymic assembly mound of Óenach Téide, while likewise, the ditch and terrace cut into the passage tomb of Knowth during the early $8^{\text {th }}$ century suggests the creation of a large stepped mound that we might legitimately associate with assembly. If these are acceptable interpretations of these sites, then they are also the only clear and well-dated examples of a purpose built assembly mounds from early medieval Ireland, and indeed, would be rare in a wider northern European context. As both examples are $8^{\text {th }}$ century in date, and ostensibly connected with broader changes in their respective landscapes, we may be witnessing the genesis of a wider phenomenon. Stepped mounds in particular are a wider Irish Sea phenomenon, though the secure evidence for an early $8^{\text {th }}$ century genesis at Knowth means that they cannot now be attributed to the Viking Age (see Driscoll 2003, 80; FitzPatrick 2004, 47; O'Grady 2008). How connected the elusive forrad discussed above are, we cannot say with certainty either, but it is notable that late $8^{\text {th }}$ - to $11^{\text {th }}$-century is a period in which assemblies become central to the formation of provinces, with laws being promulgated in their confines, as these assembly landscapes themselves became the focus of literature and place lore (Charles-Edwards 2000, 556; MacGugan 2012). Just how deeply political these motives were is hinted by a prehistoric barrow crowning Silliothill. This was undoubtedly the principal royal focus of Óenach Carmain and probably to be identified as Carn Ailbhe, 'the cairn of Ailbhe', the burial monument that 
gave its name to the parish, Carnalway. The personal female name, Ailbhe, intimates a pseudonym of Óenach Carmain, namely Óenach Ailbhe, but also an eponymic Ailbhe who was likely a queen of Uí Dunláinge, the dynasty who usurped the landscape and assembly of Óenach Carmain in the decades either side of AD 700, when adult burial ceased at Corbally, Greenhills, and Mullacash (Ó Murchadha 2002; Gleeson and Ó Carragáin 2016). As much as the use of mounds and other burial monuments as the focus of assembly practices intimates a mythologisation of these landscapes, so too do these and broader changes illuminate how places of local identity and collective action were co-opted to and influenced by processes of polity building.

\section{Conclusion}

By their very nature gatherings of large groups of people are fleeting, ephemeral and multifaceted. This has long meant that such activities are elusive in the archaeological record, but a wealth of scholarship focused on the communality, mentality and material signature of these actions has contributed a step-change in our ability to study assembly, and opened a door to archaeological contributions to understandings of governance, administration, communal action, collective identity, and the role of local society within strategies of rulership. Ireland has lagged behind in this discourse, but new research, informed to a large degree by AngloSaxon and Scandinavian scholarship, combined with new discoveries in recent decades, has allowed new approaches that broach new debates in early medieval studies and wider archaeological discourse. The discovery of so-called 'cemetery settlements' and analysis within the context of assembly places and practices is a highly significant development for early medieval Ireland, as it provides a socio-political context for these enigmatic complexes and associated landscapes, and highlights the role of transient activities as a formative force shaping political articulation. This article has aimed to show that emerging patterns within these complexes illuminate how burial created and manufactured identities and hierarchies, for example, and how the changing nature of these places illuminates assembly practices. As these complexes changed throughout the period, and their associated landscapes were re-organised, we see the evolution strategies of rulership, governance and polity building, but so too the articulation of these prerogatives with local society in a way not heretofore possible for early medieval communities in Ireland and Europe.

\section{Figure captions}


Figure 1: Map showing The Óenach Project database. Note correlation between places of early medieval burial and assembly.

Figure 2: Map showing the location of five case study assembly landscapes discussed.

Figure 3: Map showing the extent of a royal estate of Óenach Carmain and position of Silliothill (after MacCotter 2016). Note the position of Corbally, Mullacash, Coughlanstown and Greenhills around the boundaries of this estate.

Figure 4: Plan of main excavated features at Corbally (after Coyne 2010). Note the multiple foci of burial encompassed within a larger enclosure and ditch complex. (Image courtesy of Nick Hogan, UCC)

Figure 5: Photo showing the natural rock outcrop now enhanced and enclosed by a masonry wall at Carrickaneena, north Co. Louth.

Figure 6: Map showing the position of Faughaurt and Balriggan relative to Carrickaneena and petty kingdom or trícha cét boundaries c.1100 (following MacCotter 2008)

Figure 7: Map showing the location of Tullaheady, extent of the townland of Tullaheady, and proximity of Carrigatogher-Harding. The area of low ground south of Carrigatogher is the approximate course of the Slighe Dála, now the line of the M7/N7.

\section{Bibliography}

Adkins, R. A. and Petchey, M. 1984. Secklow Hundred mound and other meeting-place mounds in England. Archaeological Journal 141: 243-51.

Barnwell, Paul and Mostert, Michael eds. 2003. Political Assemblies in the Earlier Middle Ages. Turnhout: Brepols.

Bhreathnach, Edel and O'Brien, Elizabeth 2011. Irish boundary ferta: their physical manifestation and historical context. In Tome: Studies in Medieval Celtic History and Law, ed. Fiona Edmonds and Paul Russell, 53-64. Woodbridge: Boydell and Brewer.

Booth, P., Glass, H., Champion, T., Garwood, P., Munby, J. and Reynolds, A. 2011. Tracks Through Time: The Archaeology of the Channel Tunnel Rail Link. Oxford: Oxford Archaeology.

Brink, Stefan 2004. Legal assembly sites in early Scandinavia. In Assembly Places and Practices in Medieval Europe, ed. A. Pantos and S. Semple (eds.), 205-16. Dublin: Four Courts Press.

Brookes, Stuart and Reynolds, Andrew 2011. The Origins of Political Order and the AngloSaxon State. Archaeology International 13/14: 84-93. 
Buckley, Laureen and McConway, Cia 2010. Early medieval settlement and burial ground at Faughart Lower, Co. Louth. In Death and Burial in Early Medieval Ireland, ed. C. Corlett and M. Potterton, 49-60. Bray: Wordwell.

Byrne, Francis John 1968. An historical note on Cnogba. Proceedings of the Royal Irish Academy 66 (C): 383-400.

Charles-Edwards, Thomas 2000. Early Christian Ireland. Cambridge: Cambridge University Press.

Cleary, Rose and Kelleher Helen 2011. Archaeological excavations at Tullaheady Co. Tipperary. Cork: The Collins Press.

Clinton, Mark 2001. The Souterrains of Ireland. Bray: Wordwell.

Coffey, Gerald 1904. On the excavation of a tumulus near Loughrea, Co. Galway. Proceedings of the Royal Irish Academy 25 (C): 14-20.

Collins, Tracey and Lynch, Linda 2006. Excavation of Human Remains at Nenagh North, St. Conlan's Road, Nenagh, Co. Tipperary. Tipperary Historical Journal 18: 7-14.

Coyne, Frank 2010. Corbally, Co. Kildare: the results of 2003-4 excavations of a secular cemetery. In Death and Burial in Early Medieval Ireland, ed. in Christian Corlett and Michael Potterton, 77-90. Bray: Wordwell.

Delaney, Shane 2010. An early medieval landscape at Balriggan, Co. Louth. In Death and Burial in Early Medieval Ireland, ed. C. Corlett and M. Potterton, 91-102. Bray: Wordwell. Dillon, Myles 1932. Stories from the law tracts. Ériu 11: 42-65.

Doherty, Charles 1985. The monastic town in early medieval Ireland. In The comparative history of urban origins in non-Roman Europe BAR ed. H. Clarke and A. Simms, 45-75. Oxford: Archaeopress.

Driscoll, Stephen 2003. Govan: an early medieval royal centre on the Clyde. In The Stone of Destiny: artefact and icon, ed. Robert Welander, David Breeze, and Thomas Clancy, 77-84. Edinburgh: Society of Antiquaries of Scotland.

Eogan, George 2012. The Archaeology of Knowth in the $1^{\text {st }}$ and $2^{\text {nd }}$ Millennium $A D$ :

Excavations at Knowth, Vol. 5. Dublin: Royal Irish Academy.

Etchingham, Colmán 2010. The organisation and function of an early Irish church settlement: what was Glendalough?. In Glendalough: City of God, ed. C. Doherty, L. Doran and M. Kelly, 22-53. Dublin: Four Courts Press.

Ettlinger, Ellen 1953. The association of burials with popular assemblies, fairs and races in ancient Ireland. Études Celtique 6: 30-61. 
FitzPatrick, Elizabeth 2001. The Gathering Place of Tír Fhiachrach: Archaeological and Folkloric investigations of Aughris Head, Co. Sligo. Proceedings of the Royal Irish Academy 101 (C): 67-105.

FitzPatrick, Elizabeth 2004. Royal Inauguration in Gaelic Ireland, c.1100-1600: a cultural landscape study. Boydell Press: Woodbridge.

FitzPatrick, Elizabeth 2015. Assembly places and elite collective identities in Medieval Ireland. In A. Sanmark et al. (eds.) Debating the Thing in the North II, Journal of the North Atlantic, Special Edition Vol. 8: 52-69.

FitzPatrick, Elizabeth and Hennessey, Robert 2017. Finn's seat: topographies of power and royal marchlands in Gaelic polities in medieval Ireland. Landscape History 38 (2): 29-62. Gleeson, P. 2014, Landscapes of kingship in early medieval Ireland. Unpublished PhD thesis, University College Cork.

Gleeson, Patrick 2015. Kingdoms, communities and óenaig: Irish assembly practices in their Northwest European context', in A. Sanmark et al. (eds.) Debating the Thing in the North II, Journal of the North Atlantic, Special Edition Vol. 8: 33-51.

Gleeson, Patrick \& Ó Carragáín, Tomás 2016. Conversion and consolidation in Leinster’s royal heartland. In Making Christian landscapes in Atlantic Europe: conversion and consolidation in the Early Middle Ages, ed. T. Ó Carragáin and S. Turner, 75-108. Cork: Cork University Press.

Hicks, Ronald 2011. Some correlations between henge enclosures and Óenach sites. Journal of the Royal Society of Antiquaries of Ireland 139: 35-44.

Hogan, Edmund 1910. Onomasticon Goedelicum., Dublin: Four Courts Press. Hope-Taylor, Brian 1977. Yeavering: an Anglo-British centre of early Northumbria. London: HMSO.

Iversen, Frode 2013. Concilium and pagus: revisiting the early Germanic Thing-system of Northern Europe. In A. Sanmark et al. (eds.) Debating the Thing in the North II, Journal of the North Atlantic, Special Edition Vol. 8: 5-17.

Iversen, Frode 2015. Community and society: the Thing at the edge of Europe. In A. Sanmark et al. (eds.) Debating the Thing in the North II, Journal of the North Atlantic, Special Edition Vol. 8: 1-17.

Johnston, Susan and Wailes, Bernard 2007. Dún Ailinne: excavations at an Irish royal site, 1968-75. Philadelphia: Pennsylvania University Press.

Keeley, Valerie 1991. Archaeological excavation of a burial ground, Greenhills townland. Journal of the Kildare Archaeological Society 17: 180-201. 
Kelly, Fergus 1976. Audacht Morainn. Dublin: Dublin Institute for Advanced Studies. Kelly, Fergus 1997. Early Irish Farming. Dublin: Dublin Institute for Advanced Studies. Lehane, John, Muniz Pérez, Maria, O’Sullivan, Jerry and Wilkins, Bernard 2010. Three cemetery-settlement excavations in County Galway at Carrowkeel, Treanbaun and Owenbristy. In Death and Burial in Early Medieval Ireland, Christian Corlett and Michael Potterton , 139-56. Bray: Wordwell.

Logainm: The Placenames Database of Ireland. http://www.logainm.ie MacCotter, Paul 2008. Medieval Ireland: Territorial, Political and Economic Divisions. Dublin: Four Courts Press.

MacCotter, Paul 2012. Túath, manor and parish: Kingdom of Fír Maige, Cantred of Fermoy. Peritia 22: 211-48.

MacCotter, Paul 2016. Reconstructing the territorial framework for ecclesiastical and secular power structures: a case study of the kingdom of Uí Fáéláin. In Making Christian landscapes in Atlantic Europe: conversion and consolidation in the Early Middle Ages, Tomás Ó Carragáin and Sam Turner, 55-74. Cork: Cork University Press.

MacGugan, Jennifer 2012. Landscape and Lamentation: constructing commemorated space in three Middle Irish texts. Proceedings of the Royal Irish Academy 112 (C): 189-217. Mapping Death: Mapping Death: Peoples, Territories and Boundaries database. http://www.mappingdeathdb.ie

Mullins, Gerry 2007. Pagan or Christian? Excavation of a hilltop cemetery at Cross, Co. Galway'. In New routes to the past: archaeology and the National Roads Authority monograph no. 4, ed. Jerry O’Sullivan and Michael Stanley, 101-10. Dublin: National Roads Authority. Newman, Conor 2007. Procession and symbolism at Tara: analysis of the Tech Midchúarta in the context of the sacral campus. Oxford Journal of Archaeology 24 (4): 414-38.

O'Brien, Elizabeth 2009. Pagan or Christian? Burial in Ireland during the $5^{\text {th }}$ to $8^{\text {th }}$ centuries AD. In The archaeology of early medieval Celtic churches, ed. Nancy Edwards, 134-54. Leeds: Maney Publishing.

Ó Carragáin, Tomás 2009. Cemetery settlements and local churches in pre-Viking Ireland in light of comparisons with England and Wales. In Irish/Anglo-Saxon Relations before the Vikings, ed. James Graham-Campbell and Michael Ryan, 239-61. London: British Academy. Ó Carragáin, Tomás 2010. From family cemeteries to community cemeteries in Viking Age Ireland?. In Death and Burial in Early Medieval Ireland, ed. Christian Corlett and Michael Potterton 217--226. Bray: Wordwell. 
Ó Corráin, Donnchadh 1978. Nationality and kingship in pre-Norman Ireland. Historical Studies 11: 1-35.

Ødegaard, Marie 2013. State formation, administrative areas and Thing sites in the Bogarthing Law Province, southeast Norway. In A. Sanmark et al. (eds.) Debating the Thing in the North II, Journal of the North Atlantic, Special Edition Vol. 8: 42-63.

O'Grady, Oliver 2008. The setting and practice of open air judicial assemblies in medieval Scotland: a multidisciplinary study. Unpublished PhD thesis, University of Glasgow.

O'Keeffe, John 1932. Dál Caladbuig and the reciprocal services between the kings of Cashel and various Munster states. In James Fraser, Paul Grosjean and John O’Keeffe (eds.) Irish Texts, I, London: 19-21.

Ó Lochlainn, Colm 1940. Roadways in Ancient Ireland. In Féilsgríbhinn Eoin mhic Néill, ed. John Ryan, 465-74. Dublin: Sign of the Three Candles.

Ó Murchadha, Diarmait 2002. Carmain: the site of Óenach Carmain - a proposed location', Éigse 33: 57-70.

Ó Riain, Padráig, Ó Murchadha, Diarmait and Murray, Kevin 2003. Historical Dictionary of Gaelic Placenames - A. Dublin: Irish Texts Society.

O’Sullivan, Aidan, McCormick, Finbarr, Kerr, Thom and Harney, Lorcan 2013. Early medieval Ireland, $A D$ 400-1100: the evidence from archaeological excavations. Dublin: Royal Irish Academy.

Pantos, Aliki 2004. The location and form of Anglo-Saxon assembly-places: some 'moot' points. In Assembly Places and Practices in Medieval Europe, ed. A. Pantos and S. Semple, 155-80. Dublin: Four Courts Press.

Pantos, Aliki and Semple, Sarah eds. 2004. Assembly Places and Practices in Medieval Europe. Dublin: Four Courts Press.

Sanmark, Alexandra 2017. Viking law and order: places and rituals of assembly in the medieval North. Edinburgh: Edinburgh University Press.

Sanmark, Alexandra and Semple, Sarah 2013. Assembly in North West Europe: collective concerns for early societies?. European Journal of Archaeology 16 (3): 518-42.

Sanmark, Alexandra, Semple, Sarah, Mehler, Natascha and Iversen, Frode 2013. Debating the Thing in the North: selected papers from workshops organised by The Assembly Project I. Journal of the North Atlantic, Special Edition Vol. 5.

Sanmark, Alexandra, Semple, Sarah, Mehler, Natascha and Iversen, Frode 2015. Debating the Thing in the North: selected papers from workshops organised by The Assembly Project I. Journal of the North Atlantic, Special Edition Vol. 8. 
Semple, Sarah 2004. Locations of assembly in early Anglo-Saxon England. In Assembly

Places and Practices in Medieval Europe, ed. Aliki Pantos and Sarah Semple, 135-54.

Dublin: Four Courts Press

Schot, Roseanne, Newman, Conor and Bhreathnach, Edel eds. 2011, Landscapes of Cult and Kingship, Dublin: Four Courts Press

Storli, Inger 2010. Court sites of Arctic Norway: the remains of Thing sites and representations of political consolidation processes in the northern Germanic world during the First Millennium AD. Norwegian archaeological review 43 (2): 89-94.

Stout, Geraldine and Stout, Matthew 2008. Excavation of a secular cemetery at Knowth Site M, Co. Meath and related sites in north Leinster. Bray: Wordwell.

Swift, Catherine 1996. Pagan Monuments and Christian Legal Centres in early Meath. Ríocht na Midhe 9: 1-26.

Swift, Catherine 2000. Óenach Tailten, the Blackwater Valley and the early Uí Néill kings of Tara. In Seanchas: studies in early Irish history, archaeology and literature in honour of F. $J$. Byrne, ed. Alfred Smyth, 109-20. Dublin: Four Courts Press.

Swift, Catherine 2009. Commentary: The Knowth Oghams in context. In Historical Knowth: Excavations at Knowth vol.4, ed. Francis John Byrne, William Jenkins, Gillian Kenny and Catherine Swift, 120-32. Dublin: Royal Irish Academy.

Taylor, Kate 2010. An early medieval enclosure and cemetery at Carrigatogher (Harding), Co. Tipperary. In Death and Burial in Early Medieval Ireland, ed. Christian Corlett and Michael Potterton, 281-94. Bray: Wordwell.

Tobin, Red 2003. Houses, Enclosures and Kilns - Excavations at Corbally, Co. Kildare. Archaeology Ireland 17: 32-37.

Waddell, John, Fenwick, Joseph and Barton, Kevin 2009, Rathcroghan: Archaeological and Geophysical Survey in a Ritual Landscape. Bray: Wordwell.

Warner, Richard 2000. Clogher: an archaeological window in early medieval Tyrone and MidUlster. In Tyrone: History and Society, Charles Dillon, Helen Jefferies and William Nolan, 39-54. Dublin: Geography Publications.

Warner, Richard 2004. Notes on the inception and early development of the royal mound in Ireland. In Assembly Places and Practices in Medieval Europe, ed. Aliki Pantos and Sarah Semple, 27-43. Dublin: Four Courts Press.

Williams, Howard 2004. Assembling the dead. In Assembly Places and Practices in Medieval Europe, ed. Aliki Pantos and Sarah Semple, 109-34. Dublin: Four Courts Press. 
